\title{
Survey on the Industrial Logging Activities in the Businga Territory (Nord-Ubangi Province) in Democratic Republic of the Congo)
}

\author{
Koto-te-Nyiwa Ngbolua ${ }^{1}$, Armand Endowa Doikasiye ${ }^{2}$, Modeste Ndaba Modeawi ${ }^{3}$, \\ Ruphin Djolu Djoza ${ }^{4}$, Amédée Gbatea Kundana ${ }^{5}$, Colette Masengo Ashande ${ }^{6}$, Clarisse \\ Falanga Mawi $^{7}$, Ange Thijenira Loketo ${ }^{8}$, Emmanuel Moke Lengbiye9, Jonas \\ Nagahuedi Mbongu Sodi ${ }^{10}$, Muhammad Ridwan ${ }^{11}$ \\ 1,2,4,5,6Department of Environment, Faculty of Science, University of Gbado-Lite, Gbado-Lite, \\ Democratic Republic of the Congo \\ ${ }^{1}$ Abumombazi Teaching High School, Abumombazi, Province of Nord-Ubangi, Democratic Republic \\ of the Congo \\ ${ }^{3}$ Faculty of Law, University of Gbado-Lite, Gbado-Lite, Democratic Republic of the Congo \\ 7,9,10Department of Biology, Faculty of Science, University of Kinshasa, Kinshasa, Democratic \\ Republic of the Congo \\ ${ }^{8}$ Department of Geoscience, Faculty of Science, University of Kinshasa, Kinshasa, Democratic \\ Republic of the Congo \\ ${ }^{11}$ Universitas Islam Negeri Sumatera Utara, Indonesia \\ Email: mailto:jpngbolua@unikin.ac.cd
}

\begin{abstract}
:
The aim of this study was to investigate industrial logging in Businga Territory. The survey was carried out by means of a questionnaire addressed to 235 people including 150 men (64\%) and 85 women (36\%) between 31 and 100 years of age, on the basis of free and informed consent. It emerged from this study that 110 subjects out of the 235 (46.8\%) were from SICOTRA company and its surroundings and 125 respondents (53.2\%) belonged to from KKF company and its surroundings. Of the 235 people surveyed, only 104 (or 44.3\%) were workers from two companies, the restwere heads of groups, capitas, local notables and those who had not worked in either company. $44.6 \%$ of the respondents had a primary level followed by $31.9 \%$ (or 75 people) with a secondary level. There are 55 illiterate people (23.4\%). No university executives were met in the area during the survey. The logging by these two companies (KKF: from 1949 to 1998 (49 years of exploitation) and SICOTRA:from 1980 to 1998 (18 years)) has caused enormous destruction of the ecosystem and the population is today confronted with multiple difficulties and problems of supply of Non Timber Forest Products (caterpillars, snails, mushrooms, Cola acuminata, etc.) and the erosion of biodiversity. Of the 17 forest species exploited in this Sector, 03 have totally disappeared: Diospyros crassiflora Hiern, Nauclea diderrichii (De Wild.) Merr. and Prioria balsaminfera (Vermoesen) Breteler. The majority contacted had no notion of protecting the forest $(67.2 \%$ vs. $32.8 \%)$; the population had no notion of drawing up specifications (95 vs. 5\%). The results revealed that the indigenous population did not benefit from their forest, nor did they benefit from basic social infrastructures of community interest. In order to remedy this situation, a good regulation of the forestry exploitation code, the popularization of the new forestry code and the elaboration of specifications in collaboration with local communities are necessary to correct this situation in the future.
\end{abstract}

Keywords:

forest; useful species; SICOTRA; KKF; Nord-Ubangi 


\section{Introduction}

The forests of the Democratic Republic of Congo (DRC) are estimated at 155 million hectares and cover more than $60 \%$ of the national territory. They constitute the largest forest massif in the Congo Basin (47\%) which is the second largest tropical forest lung behind the Amazonian forests. These forests of exceptional biological diversity play a fundamental role in the survival of the 35 million Congolese people who depend on them [1-3]. They provide them with firewood and construction wood [4, 5], medicines [6-14], food and other goods and services $[15,17]$, etc. They are also the source of many other goods and services $[16,18]$. With the aim of preserving its forests and responding to international recommendations in this area, the DRC has been undertaking reforms in this sector since August 2002. These have materialized in the drafting of the Forest Code, a legal framework designed to address the many problems related to the loss of forest cover and biodiversity.

The major advances of these reforms have been the conversion of old titles into new ones called "concession contracts", the taking into account of the concerns of local communities in terms of usage rights and above all the obligation to carry out a manage ment plan; this emphasizes the conservation of biodiversity and the maintenance of the ecological, economic and social functions of the forests being exploited. Thus, by means of these regulatory measures of control and monitoring, industrial forestry has become truly in line with the logic of sustainable development by guaranteeing the management of the forests, removing them from other alternative uses that destroy the forest cover [18-20].

Beyond improving the contribution of the forestry sector to the national economy, the socio-economic benefits of such reforms are not negligible. With 15 million hectares devoted to it and although its contribution to State revenues is still small (around 1\% of GDP) compared to other countries in the Congo Basin, the sector employs around 15,000 direct workers. Articles 89 and 122 of the Forestry Code, which respectively provide for the negotiation of social clauses in the logging specifications by the logger in favor of local communities, guaranteeing them certain facilities, and the payment of taxes and surface royalties, $15 \%$ of which are retroceded to the decentralized entity concerned by the logging operation, are measures that greatly contribute to limiting management conflicts in the area and to ensuring subsequent development in the logged area [20]. However, despite these few legal and structural advances in the sector, and despite the existence of recurrent administrative problems, the financial crisis of 2008 slowed down this momentum and negatively impacted the sector. Many companies, particularly those involved in industrial logging, which in the DRC are largely owned by foreign investors, went bankrupt.

In Nord-Ubangi province, for example, SICOTRA CONGO and KKF have not been spared and are currently out of business, which from a socio-economic point of view is a real problem in this part of the country, which is landlocked and where extreme poverty prevails $[15,16]$. While it has been shown that the presence of a logging company operating in an environment and under conditions of respect for the laws and principles in this area can be very advantageous both for the populations and for the economy of the region concerned, the situation is not very reassuring in the event of bankruptcy of the company and especially in the present conditions of the DRC's forestry sector.

The aim of this study was to investigate industrial logging in the Businga Territory (Nord-Ubangi province) in the Democratic Republic of the Congo. 


\section{Research Methods}

The present study was carried out in the Businga sector (Figure 1) in the Nord-Ubangi Province in the Democratic Republic of Congo; Geographical coordinates: $4^{\circ} 22^{\prime}$ north latitude; $22^{\circ} 2^{\prime}$ east longitude; Altitude: $200 \mathrm{~m}$ above sea level. This part of DRC belongs to the Ubangi eco-region, a subgroup of Northeastern Congolian lowland forests. This ecoregion is one of the 200 globally priority terrestrial eco-regions known as the "G200" [15, 16, 21]. To collect the data, a sample of 235 subjects was drawn, made up of administrative staff and workers of the companies KKF and SICOTRA CONGO, living in the localities of Bobale and Mongbengbe. Respondents were subjected to a questionnaire, accompanied by a few interviews and interviews. The main data collected during the survey is related to gender, age, level of study, origin of respondents, ethnicity, logging company, forest protection and the elaboration of specifications. At the level of each worker's camp, only the odd-numbered plots were visited. A raid on the different logging sites of the companies made it possible to observe the level of degradation of the forest and to see the negative impact of logging on the environment.

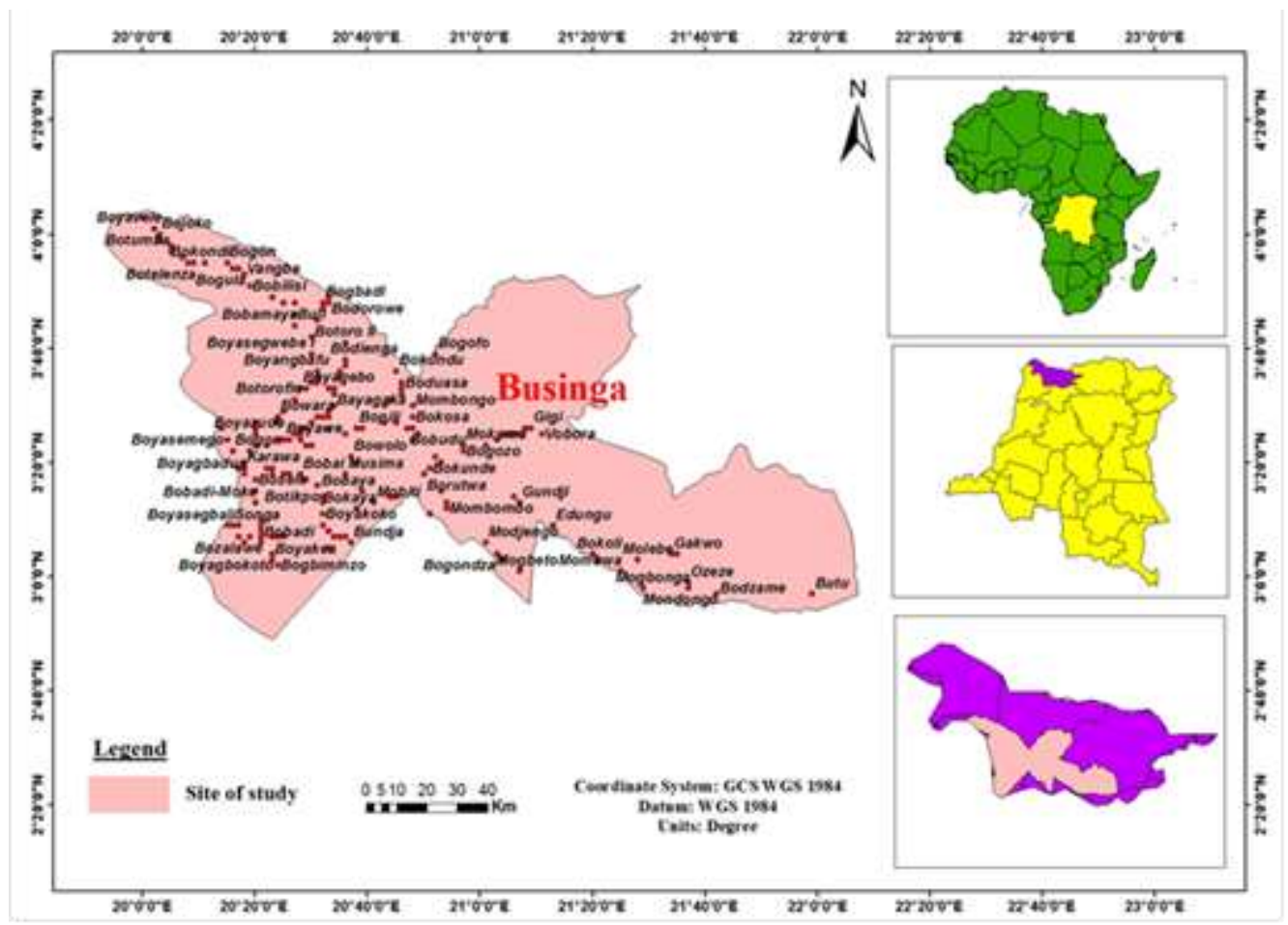

Figure 1. Site of survey (Businga sector)

\section{Discussion}

The survey was conducted among 235 people, including 150 men (64\%) and 85 women $(36 \%)$ between the ages of 31 and 100. Figure 2 shows the distribution of respondents by age group. 


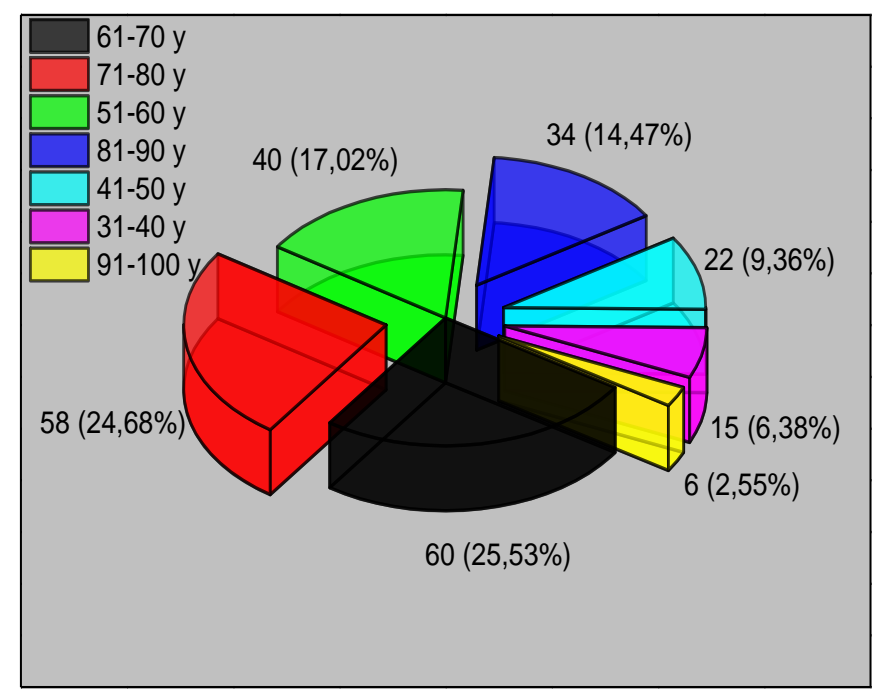

Figure 2. Age Range of Respondents

It can be seen from this figure that many of the respondents are in the 61-70 age group $(25.53 \%)$, followed by those aged 71-80 (24.68\%); 51-60 (17\%); $81-90$ (14.46\%); 31-40 $(6.38 \%)$ and $91-100(2.55 \%)$ respectively. Figure 3 shows the distribution of respondents according to the sampled companies.

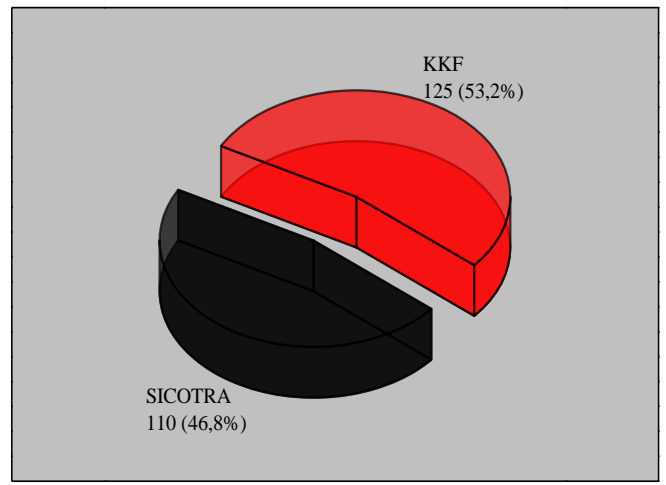

Figure 3. Distribution of Respondents by Operating Company

The figure 3 shows that 110 subjects, i.e. 46.8\%, come from SICOTRA and its surroundings and 125 respondents, i.e. $53.2 \%$, belong to KKF and its surroundings. Table 1 shows the distribution of respondents according to their professional category.

Table 1. Professional Category of Respondents

\begin{tabular}{|c|c|c|c|c|c|c|c|c|}
\hline \multirow[b]{3}{*}{ CATEGORY } & \multicolumn{6}{|c|}{ Staff } & \multirow[b]{3}{*}{ TOTAL } & \multirow[b]{3}{*}{$\%$} \\
\hline & \multicolumn{3}{|c|}{ KKF/MONGBENGBE } & \multicolumn{3}{|c|}{ SICOTRA/BOBALE } & & \\
\hline & $\mathrm{H}$ & $\mathrm{F}$ & $\mathrm{T}$ & $\mathrm{H}$ & $\mathrm{F}$ & $\overline{\mathrm{T}}$ & & \\
\hline Group leader & 1 & 0 & 1 & 0 & 1 & 1 & 2 & 0,9 \\
\hline Capitas & 5 & 0 & 5 & 2 & 0 & 2 & 7 & 2,9 \\
\hline Notables & 5 & 0 & 5 & 2 & 0 & 2 & 7 & 2,9 \\
\hline
\end{tabular}




\begin{tabular}{|l|c|c|c|c|c|c|c|c|}
\hline Workers & 60 & 0 & 60 & 44 & 0 & 44 & 104 & 44,3 \\
\hline No workers & 24 & 30 & 54 & 31 & 30 & 61 & 115 & 49,0 \\
\hline TOTAL & 95 & 30 & 125 & 79 & 31 & 110 & 235 & 100 \\
\hline
\end{tabular}

The Table 1 shows that out of 235 people surveyed, 104 people, or $44.3 \%$, were workers in two firms, the rest being group leaders, capitas, middle-class notables and those who did not work in either firm. The respondents were distributed as follows: in Mongbengbe (95 men and 24 women, representing 125 subjects or 53.1\%); in Bobale (79 men and 31 women, representing 46.9\%). Mongbengbe is more represented for the simple reason that many people live in the workers' camp built by the company. Neither company employed women. Figure 4 shows the educational level of the respondents.

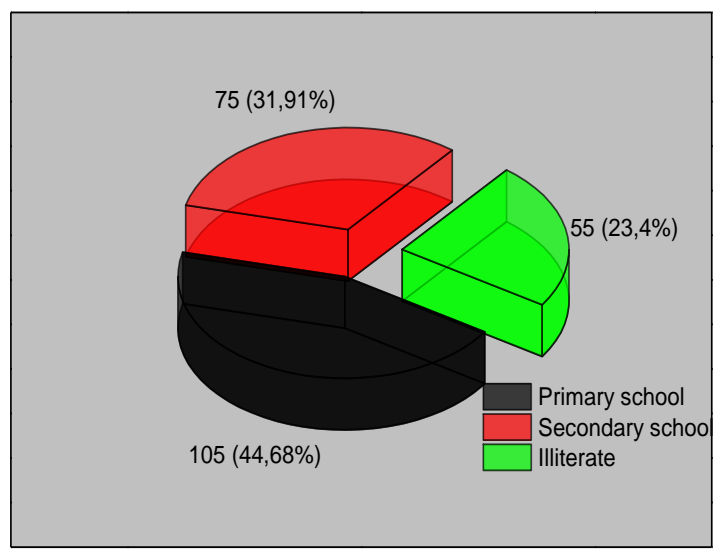

Figure 4. Respondents' Level of Education

The figure 4 shows that $44.6 \%$ of respondents have a primary level followed by $31.9 \%$ (75 people) with a secondary level. There are 55 illiterate people (23.4\%). No university executives were met in the area during the survey. As a result, the population has no data or documents showing the agreement between the indigenous people and the farmers. They only have some verbal information from the Chief of the Group, the Notables and a few older people in the village. Figure 5 shows the origin of the respondents.

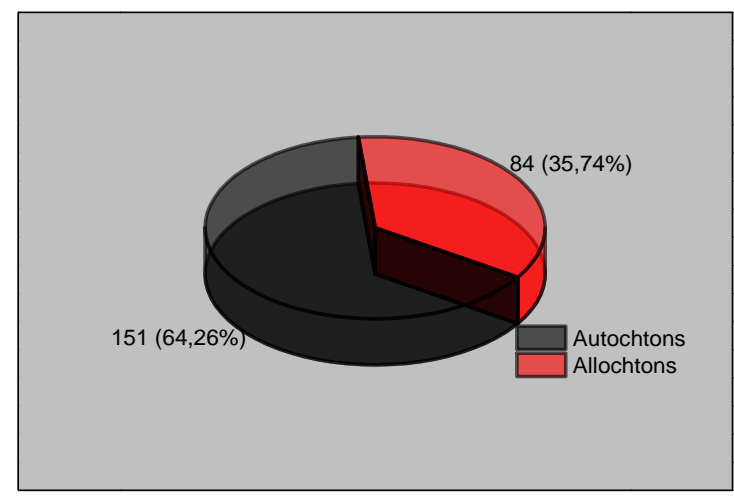

Figure 5. Origin of Respondents

This figure shows that 151 respondents $(64.26 \%)$ are from the middle, while the rest $(84$ subjects, or $35.74 \%$ ) constitute the imported labor force, mainly from South Ubangi, and a few others who work in the administration. Table 2 shows the distribution of respondents according to their ethnic origin. 
Table 2. Distribution of Respondents According to Ethnic Origin

\begin{tabular}{|c|c|c|c|c|}
\hline \multirow[b]{2}{*}{ Ethnicity } & \multicolumn{2}{|c|}{ Staff } & \multirow[b]{2}{*}{ TOTAL } & \multirow[b]{2}{*}{$\%$} \\
\hline & MONGB ENGB E/KKF & BOBALE/SICOTRA & & \\
\hline Ngbandi & 63 & 17 & 78 & 33,19 \\
\hline Ngbaka & 46 & 13 & 61 & 25,96 \\
\hline Mbanza & 3 & 70 & 73 & 31,06 \\
\hline Ngombe & 7 & 0 & 7 & 2,98 \\
\hline Budja & 7 & 1 & 8 & 3,40 \\
\hline Pakabete & 8 & 0 & 8 & 3,40 \\
\hline TOTAL & 125 & 110 & 235 & 100 \\
\hline
\end{tabular}

This table shows that 78 respondents (33.19\%) were Ngbandi; 73 respondents (31.06\%) were Mbanza; the Ngbaka numbered 61 (25.96\%); followed by Pakabete and Budja with 8 subjects each (3.40\%) and the Ngombe, 7 respondents $(2.98 \%)$. The Ngbandi dominate in Mongbengbe in the MBATI group (site of the KKF company) while the Mbanza are in the majority in the BOBALE group (area of operation of the SICOTRA company). The Ngbaka were recruited to support the labor force; the Ngombe and Budja worked in the administration; the Pakabete are the neighbors of the Ngbandi and most of this population was not interested in logging because their main activity is hunting.

The table 3 shows the level of knowledge and attitude of the population rega rding industrial logging in the Businga territory (Nord-Ubangi province) in the Democratic Republic of the Congo, particularly with regard to forest protection, the drawing up of specifications and the respondents' appreciation of the logging companies.

Table 3. Knowledge and Attitudes of the Population

\begin{tabular}{|c|c|c|}
\hline No & Questions \& Answers & $\begin{array}{c}\text { Frequency } \\
(\%)\end{array}$ \\
\hline \multirow[t]{3}{*}{1} & Do you have any knowledge about forest protection? & - \\
\hline & 0 Yes & $77(32.8 \%)$ \\
\hline & $\circ \quad$ No & $158(7.2)$ \\
\hline \multirow[t]{3}{*}{2} & Do you have any knowledge about drawing up specifications? & - \\
\hline & O Yes & $12(5 \%)$ \\
\hline & $\circ \quad$ No & $223(5 \%)$ \\
\hline \multirow[t]{3}{*}{3} & How do you appreciate the departure of loggers? & - \\
\hline & ○ Favorable & $110(46.8 \%)$ \\
\hline & o Not favorable & $125(53.2 \%)$ \\
\hline
\end{tabular}

The results of our surveys indicate that out of a total of 235 individuals, 77 people (53 men and 24 women) or $32.8 \%$ have heard of forest protection compared to 158 (97 men and 61 women) or $67.2 \%$ who have never heard of it. Many of them have no knowledge of how to draw up specifications $(95 \%$ vs. $5 \%$ ). It should be noted that these 12 people were members of the Company's administrative staff and not originally from the community. Among the 235 subjects surveyed, many did not want the operators to leave $(53.2 \%$ vs. $46.8 \%)$.

Several women were of the opinion that the farmers should leave. In fact, the poor management of salary funds destabilized the peaceful atmosphere in the family.

The bankruptcy of the businesses was welcomed by the women, who saw their husbands released to ensure that they could properly fulfill their obligations, particularly to stay at home, clear the fields and regularly accompany them to the field. The table 3 lists the forest species exploited in Businga and their characteristics. 
Table 3. Some Exploited Forest Plant Species and Their Characteristics

\begin{tabular}{|c|c|c|c|c|c|c|c|c|c|c|}
\hline $\mathbf{N}^{\circ}$ & $\begin{array}{l}\text { Trade } \\
\text { Name }\end{array}$ & $\begin{array}{l}\text { Vernacular } \\
\text { Name }\end{array}$ & Scientific Name & Family & Class & DME & AAM & MT & Category & AAM \\
\hline 1 & Latandza & $\begin{array}{l}\text { Libamba } \\
\text { (Pakabete) }\end{array}$ & $\begin{array}{l}\text { Albizia ferruginea } \\
\text { (Guill. \& Perr.) Benth. }\end{array}$ & Leguminosae & II & 60 & 0.5 & A & $\overline{\mathrm{VU}}$ & 0.5 \\
\hline 2 & Mukulungu & $\begin{array}{l}\text { Mokungu } \\
\text { (Mbanza) }\end{array}$ & $\begin{array}{l}\text { Autranella congolensis } \\
\text { (De Wild.) A.Chev. }\end{array}$ & Sapotaceae & $T$ & 80 & 0.5 & A & $\mathrm{CR}$ & 0.5 \\
\hline 3 & Bomanga & - & $\begin{array}{l}\text { Brachystegia laurentii } \\
\text { (De Wild.) Hoyle }\end{array}$ & Leguminosae & II & 80 & 0.5 & $\bar{A}$ & $\overline{\mathrm{LC}}$ & 0.5 \\
\hline 4 & $\begin{array}{l}\text { Kaya } \\
\text { kwakwa }\end{array}$ & - & $\begin{array}{l}\text { Caloncoba glauca } \\
\text { (P.Beauv.) Gilg }\end{array}$ & Achariaceae & TV & 60 & 0.5 & $\mathrm{~A}$ & - & 0.5 \\
\hline 5 & $\begin{array}{l}\text { Longhi } \\
\text { rouge }\end{array}$ & - & $\begin{array}{l}\text { Chrysophyllum } \\
\text { lacourtianum De Wild. }\end{array}$ & Sapotaceae & II & 60 & 0.5 & $\bar{A}$ & $\overline{\mathrm{LC}}$ & 0.5 \\
\hline 6 & Ebene noir & $\begin{array}{l}\text { Ngale } \\
\text { (Ngbandi) }\end{array}$ & $\begin{array}{l}\text { Diospyros crassiflora } \\
\text { Hiern }\end{array}$ & Ebenaceae & $\mathrm{T}$ & 50 & 0.18 & A & EN & 0.18 \\
\hline 7 & $\begin{array}{l}\text { Tiama } \\
\text { blanc }\end{array}$ & $\begin{array}{l}\text { Mboyo } \\
\text { (blanc) } \\
\text { (Ngbandi) }\end{array}$ & $\begin{array}{l}\text { Entandrophragma } \\
\text { angolense (Welw.) } \\
\text { C.DC. }\end{array}$ & Meliaceae & $\mathrm{I}$ & 80 & 0.5 & $\bar{A}$ & $\overline{\mathrm{VU}}$ & 0.5 \\
\hline 8 & Kosipo & $\begin{array}{l}\text { Mboyo } \\
\text { (brun) } \\
\text { (Ngbandi) }\end{array}$ & $\begin{array}{l}\text { Entandrophragma } \\
\text { candolei Harms }\end{array}$ & Meliaceae & $\mathrm{T}$ & 80 & 0.46 & $\bar{A}$ & $\mathrm{VU}$ & 0.46 \\
\hline 9 & Sipo & $\begin{array}{l}\text { Mboyo } \\
\text { (rouge) } \\
\text { (Ngbandi) }\end{array}$ & $\begin{array}{l}\text { Entandrophragma } \\
\text { utile (Dawe \& } \\
\text { Sprague) Sprague }\end{array}$ & Meliaceae & I & 80 & 0.61 & $\mathrm{~A}$ & $\mathrm{VU}$ & 0.61 \\
\hline 10 & Limbali & $\begin{array}{l}\text { Godo } \\
\text { (Ngbandi) }\end{array}$ & $\begin{array}{l}\text { Gilbertiodendron } \\
\text { dewevrei (De Wild.) } \\
\text { J.Leonard }\end{array}$ & Leguminosae & TII & 60 & 0.4 & A & $\mathrm{LC}$ & 0.4 \\
\hline 11 & $\begin{array}{l}\text { Acajou } \\
\text { d'Afrique }\end{array}$ & $\begin{array}{l}\text { Ngola } \\
\text { (Lingala) }\end{array}$ & $\begin{array}{l}\text { Khaya anthotheca } \\
\text { (Welw.) C.DC. }\end{array}$ & Meliaceae & $\mathrm{T}$ & 80 & 0.7 & $\bar{A}$ & $\mathrm{VU}$ & 0.7 \\
\hline 12 & Iroko & $\begin{array}{l}\text { Mbangi } \\
\text { (Ngbandi) }\end{array}$ & $\begin{array}{ll}\text { Milicia } & \text { excelsa } \\
\text { (Welw.) C. C. Berg }\end{array}$ & Moraceae & $\mathrm{I}$ & 80 & 0.53 & A & $\mathrm{LR} / \mathrm{nt}$ & 0.53 \\
\hline 13 & Bisingi & $\begin{array}{l}\text { Gangba } \\
\text { (Ngbandi) }\end{array}$ & $\begin{array}{l}\text { Nauclea diderrichii } \\
\text { (De Wild.) Merr. }\end{array}$ & Rubiaceae & $\mathrm{I}$ & 60 & 0.38 & $\bar{A}$ & $\mathrm{VU}$ & 0.38 \\
\hline 14 & Tola blanc & & $\begin{array}{l}\text { Prioria balsaminfera } \\
\text { (Vermoesen) Breteler }\end{array}$ & Leguminosae & $\mathrm{I}$ & 80 & 0.45 & A & EN & 0.45 \\
\hline 15 & Limba & $\begin{array}{l}\text { Gbanga } \\
\text { (Ngbandi) }\end{array}$ & $\begin{array}{l}\text { Terminalia superba } \\
\text { Engl. \& Diels }\end{array}$ & Combretaceae & $\mathrm{I}$ & 60 & 0.94 & A & - & 0.94 \\
\hline 16 & Obonvogo & $\begin{array}{l}\text { Mbolongo } \\
\text { (Ngbandi) }\end{array}$ & $\begin{array}{lr}\text { Zanthoxylum } & \text { gilletii } \\
\text { (De Wild.) } & \text { P.G. } \\
\text { Waterman } & \end{array}$ & Rutaceae & III & 60 & 0.7 & $\bar{A}$ & $\overline{\mathrm{LC}}$ & 0.7 \\
\hline
\end{tabular}

Legend: Class I - Species with proven economic potential: This class includes all woodworking and construction species; Class II: Other species with commercialpotential; Class III: Species to be promoted; Class IV includes all species other than those found in classes I, II and III. DME: Minimum Exploitation Diameter (in cm); AAM: Average Annual Growth Rate (in cm); MT (morphological type): "a": shrub and "A": tree. 
From this table, it can be seen that Businga Forest contains 16 economically useful tree species exploited by the two logging companies. These plants are divided into 14 genera and 09 botanical families of which only three are the most represented. These are: Leguminosae (4 species), Meliaceae (4 species) and Sapotaceae (2 species) (Figure 6).

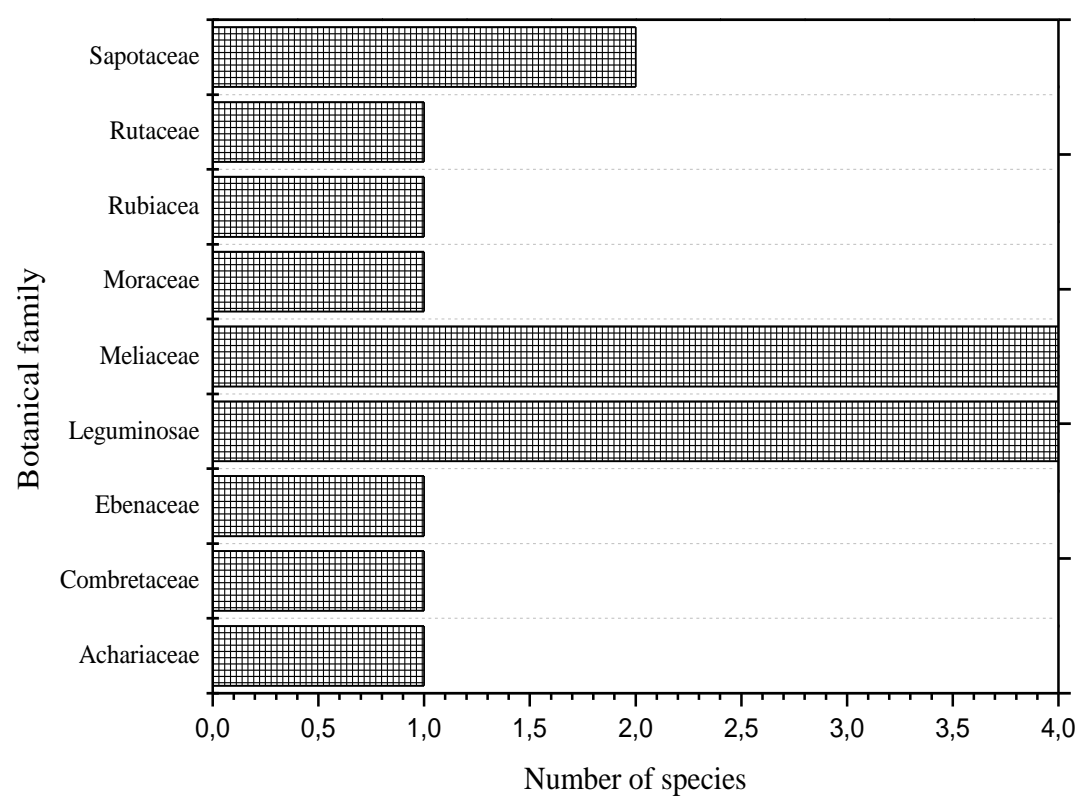

Figure 6. Number of Species Exploited as a Function of Botanical Family

According to the DIAF recommendation (2017), 10 species exploited (62.5\%) belong to Class I (species with proven economic potential); 3 out of 16 species $(18.75 \%)$ belong to Class II (other species with commercial potential), two species belong to Class III (species to be promoted) and only one species is in Class IV (species other than those found in Classes I, II and III) (Figure 7).

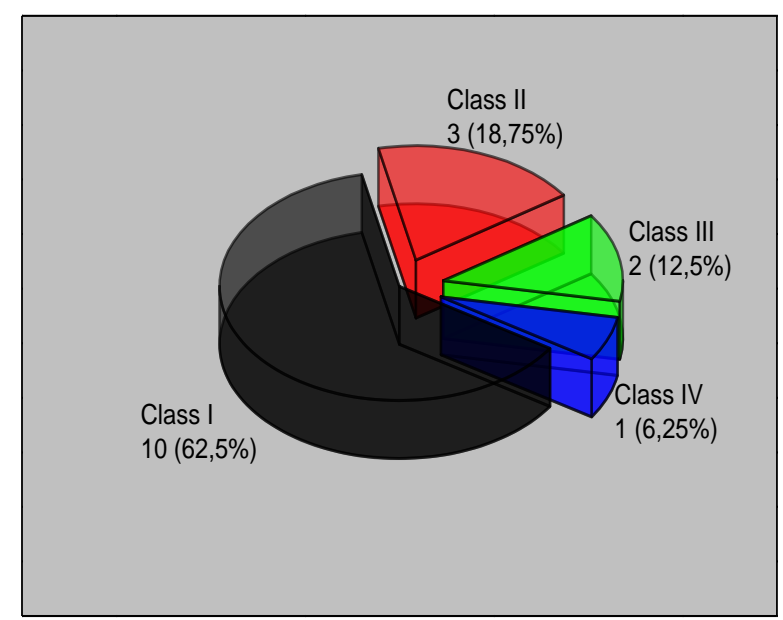

Figure 7. Economic Classification of Tree Species Exploited in Businga

The exploitation of the forests in Businga by these two companies (KKF: from 1949 to 1998 or 49 years of exploitation and SICOTRA: from 1980 to 1998 or 18 years) (figure 8) has led to the destruction of the ecosystem and the population is today confronted with multiple difficulties and problems of supply of Non Timber Forest Products (caterpillars, 
snails, mushrooms, Cola acuminata, etc.) and the erosion of biodiversity. Indeed, certain species, plant and animal, are becoming increasingly rare and the distances travelled to find them in the forest are greater and greater.

As the forest is far away, the population has difficulty in obtaining supplies of bushmeat due to the destruction of habitats and ecological niches of certain species. Today we are witnessing the total disappearance of some economically valuable forest species such as Diospyros crassiflora Hiern, Nauclea diderrichii (De Wild.) Merr. and Prioria balsaminfera (Vermoesen) Breteler. Although the forests of Mongbengbe and Bobale are exploited, no action in terms of improving the social conditions of the local populations has been carried out by the loggers, nor even by their successors, apart from a few donations offered to the Notables at the end of each year ( 3 sacks of salt per person, red wine, a cigarette pack, a lump sum of money). This spirit violates the principles of sustainable development which requires a dynamic balance between the environment and human activities. The social issues related to the processes of transformation of society in a sustainable development perspective require the training of local actors hence necessitating a prior compromise between entrepreneurs and the local population and strict respect for the closes. Indeed, the concept of "participatory management" which allows combining socio-economic development with nature conservation is the best alternative for the sustainable development of African societies.

Thus, during the negotiations of future social clause agreements, the stakeholders should refer to the economic classification of forest species for the determination of the unit rate per species and per $\mathrm{m} 3$ for the calculation of the rebate provided for in Article 11 of Law 023/CAB/MIN/ECN-T/28/JEB/10 of June 7, 2010 [22].
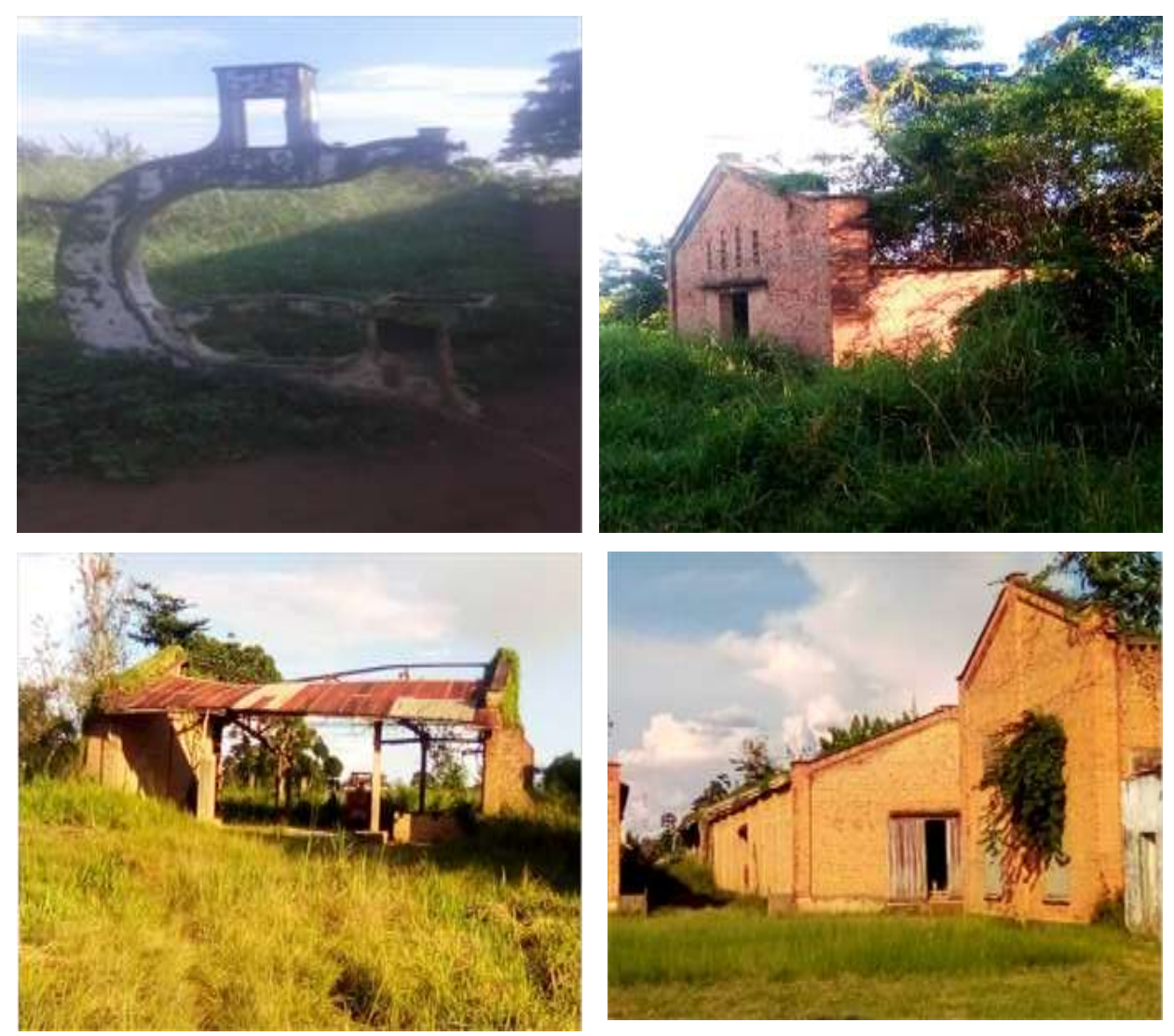

Figure 8. Landscape of the Headquarters of These Two Companies 

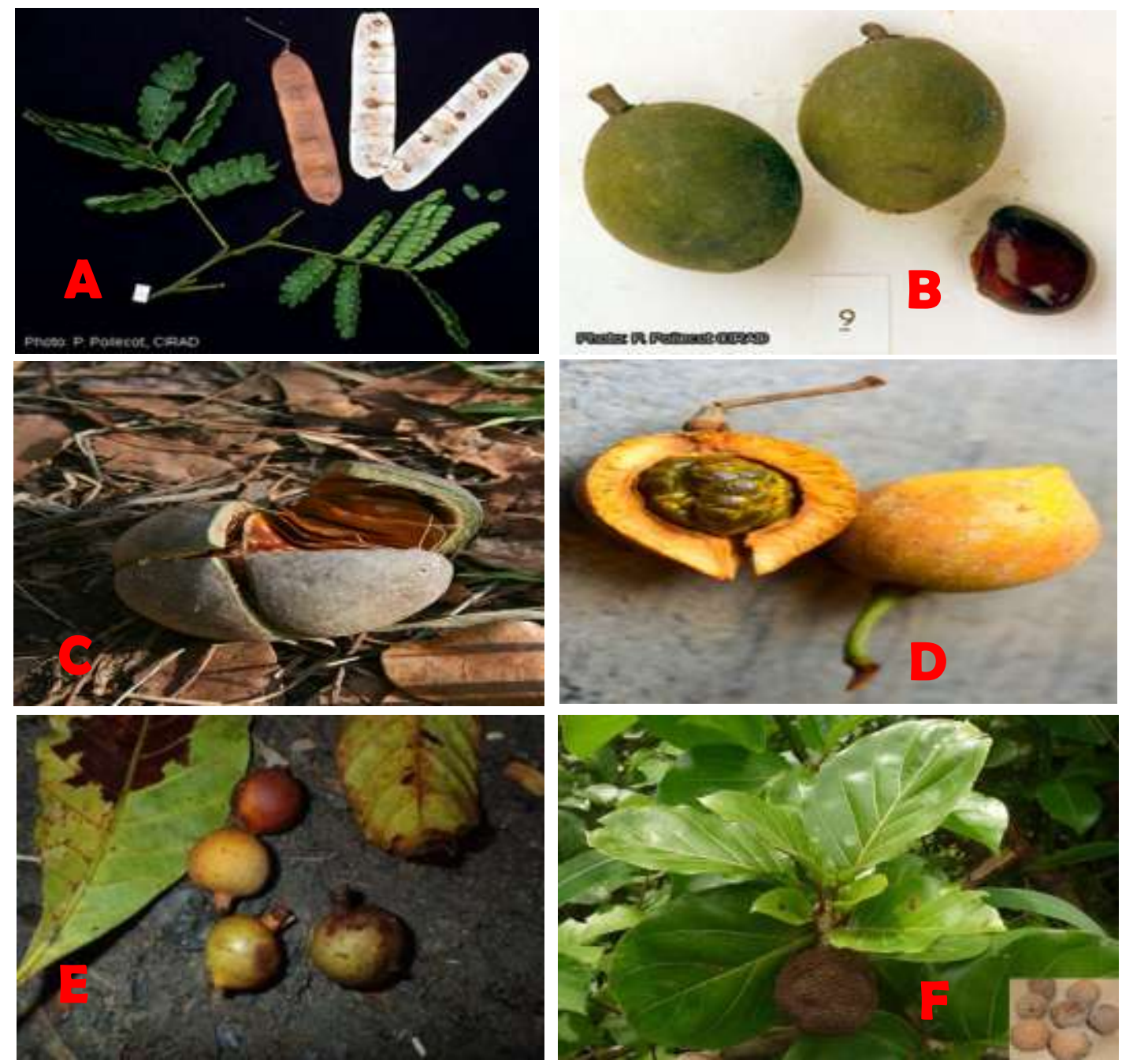

Figure 9. Some exploited plant species [A] Albizia ferruginea (Guill. \& Perr.) Benth.; [B] Autranella congolensis (De Wild.) A.Chev. ; [C] Khaya anthotheca (Welw.) C.DC.; [D] Caloncoba glauca (P.Beauv.) Gilg ; [E] Chrysophyllum lacourtianum De Wild. ; [F] Nauclea diderrichii (De Wild.) Merr.

\section{Conclusion}

The purpose of this study was to investigate industrial logging in the Businga Territory (North Ubangi) in the Democratic Republic of Congo. The study found that two companies have logged 17 different species of timber in the area. The indigenous population has not benefited from its forest or from basic social infrastructure of community interest. The impact of this activity on the environment is characterized by the total disappearance of some economic forest species [Diospyros crassiflora Hiern, Nauclea diderrichii (De Wild.) Merr.) and Prioria balsaminfera (Vermoesen) Breteler]; the scarcity of NTFPs and bush meat and the degradation of this forest massif.

Good regulation of the forestry exploitation code; the popularization of the new forestry code and the elaboration of specifications by local communities are necessary to correct this situation in the future. 


\section{References}

[1] Omatoko J, Nshimba H, Bogaert J, Lejoly J, Shutsha R, Shaumba JP, Asimonyio J, Ngbolua KN (2015). Études floristique et structurale des peuplements sur sols argileux à Pericopsis elata et sableux à Julbernardia seretii dans la forêt de plaine de UMA en République Démocratique du Congo. International Journal of Innovation and Applied Studies 13: 452-463.

[2] FAO/OIBT (2011). La situation des forêts dans le bassin amazonien, le bassin du Congo et l'Asie du Sud-Est. Rapport préparé pour le sommet des trois bassins forestiers tropicaux. Brazzaville, République du Congo.

[3] Bolia NE, Bosanza JBZ, Mongeke MM, Ngbolua KN (2019). Études dendrométrique et floristique des forêts à Gilbertiodendron dewevrei d'une concession forestière en République Démocratique du Congo. Rev. Mar. Sci. Agron. Vét. 7 (1): 110-117.

[4] Ngbolua KN, Ndanga BA, Gbatea KA, Djolu DR, Ndaba MM, Masengo AC, Likolo BJ, Falanga MC, Yangba TS, Gbolo ZB, Mpiana PT (2018). Environmental Impact of WoodEnergy Consumption by Households in Democratic Republic of the Congo: A Case Study of Gbadolite City, Nord-Ubangi. International Journal of Energy and Sustainable Development 3(4): 64-71.

[5] Ngbolua KN, Ngemale GM, Masengo AC, Motende BN, Ndolete G, Djolu DR, Libwa MTB, Bongo NG (2019). Evaluation of Artisanal Logging Sector in Democratic Republic of the Congo: A Case Study of Peri-urban Forest of Gbadolite City, NordUbangi. International Journal of Plant Science and Ecology 5(2): 25-30.

[6] Inkoto LC, Bongo NG, Kapepula MP, Masengo AC, Gbolo ZB, Tshiama C, Ngombe KB, Iteku BJ, Mbemba FT, Mpiana PT, Ngbolua KN (2018). Microscopic features and chromatographic fingerprints of selected congolese medicinal plants: Aframomum alboviolaceum (Ridley) K. Schum, Annona senegalensis Pers. and Mondia whitei (Hook.f.) Skeels. Emergent Life Sciences Research 4(1): 1-10.

[7] Ipona EN, Inkoto CL, Bongo GN, Mulenga CM, Ilinga BL, Shetonde OS, Mbala BM, Tshilanda DD, Mvingu BK, Kayembe JS, Mpiana PT, Ngbolua KN (2019). EthnoBotanical Survey and Ecological Study of Medicinal Plants Traditionally Used Against Erectile Dysfunction in Democratic Republic of the Congo; Bioscience and Bioengineering 4(4): 85-91.

[8] Ngbolua KN, Ambayi BS, Bongo NG, Masengo AC, Djolu DR, Likolo BJ, Gbolo ZB, Ngunde-te-Ngunde S, Iteku BJ, Mpiana PT (2017). Ethno-botanical survey and floristic study of medicinal plant taxa used by Traditional Healers in Gbadolite city (Province of Nord-Ubangi, Congo-Kinshasa). J. of Modern Drug Discovery and Drug Delivery Research. V5I2. DOI: 10.5281/zenodo.1116857.

[9] Mongeke MM, Ngbolua KN, Bakola RD, Inkoto CL, Elikandani PN, Mowuli CY (2018). Enquête sur les plantes utilisées en Médicine Traditionnelle par les Ba mbenga: Pygmées du Secteur de Dongo (Territoire de Kungu, Province du Sud-Ubangi) en République démocratique du Congo. Revue Marocaine des Sciences Agronomiques et Vétérinaires; ev. Mar. Sci. Agron. Vét. 6(4): 469-475.

[10] Katemo M, Mpiana PT, Mbala BM, Mihigo SO, Ngbolua KN, Tshibangu DST, Koyange PR (2012). Ethno-pharmacological survey of plants used against diabetes in Kisangani city (D.R. Congo). Journal of Ethnopharmacology 144: 39-43.

[11] Mulwele FN, Ngbolua KN, Yang BD-MM, Mpiana PT (2016). Ethno-botanical and ecological studies of plant species used in the treatment of sterility in Kenge city and its surroundings (Province of Kwango, Democratic Republic of the Congo).International Journal of Innovation and Scientific Resarch 26(2): 600-611.

[12] Ngbolua KN, Inkoto CL, Mongo LN, Masengo AC, Masens Da-Musa YB, Mpiana PT (2019). Etudes ethnobotanique et floristique de quelques plantes médicinales 
commercialisées à Kinshasa, République Démocratique du Congo. Rev. Mar. Sci. Agr. Vet. 9(1): 7 (1): 118-128.

[13] Ngbolua KN, Mandjo BL, Munsebi JM, Masengo CA, Lengbiye EM, Asamboa LS, Konda RK, Dianzuangani DL, Ilumbe M, Nzudjom AB, Kadimanche M, Mpiana PT (2016e). Études ethnobotanique et écologique des plantes utilisées en médecine traditionnelle dans le District de la Lukunga à Kinshasa (RD du Congo). International Journal of Innovation and Scientific Research 26: 612-633.

[14] Masunda AT, Inkoto CL, Bongo GN, Wa Oloko J-D, Ngbolua KN, Tshibangu DST, Tshilanda DD, Mpiana PT (2019). Ethnobotanical and Ecological Studies of Plants Used in the Treatment of Diabetes in Kwango, Kongo Central and Kinshasa in the Democratic Republic of the Congo; International Journal of Diabetes and Endocrinology 4(1): 18-25

[15] Ngbolua KN, Ngemale GM, Masengo AC, Ndolete GJP, Bongo NG, Ndanga BA, Tshibangu DST, Tshilanda DD (2020). Survey on the Sale of Megaphrynium Macrostachyum (Marantaceae) Leaves in Gbado-Lite City and Surroundings (Nord Ubangi Province, Democratic Republic of the Congo). Budapest International Research in Exact Sciences (BirEx) Journal 2(2): 157-167.

[16] Ngbolua KN, Nzamonga GA, Gbatea KA, Nzale MS, Masengo AC, Ndolete G, Bongo NG, Zakwani LN, Libwa MTB, Yangba TS, Gerengbo KG (2019). Knowledge on NonTimber Forest Products (NTFPs) Marketed in Democratic Republic of the Congo: A Case Study of Gbadolite City and Surroundings, Nord Ubangi. Agricultural and Biological Sciences Journal 5(1): 20-28.

[17] Ngbolua KN, Ambayi BS, Bongo NG, Djolu DR, Nzamonga GA, Masengo AC, Koyagialo JL, Gbatea KA,. Ndaba MM, Kowozogono KR (2017). Preliminary survey on the bushmeat sector in Nord-Ubangi Province (DR Congo): Case of Gbado-Lite city and its surroundings. J. Advanced Botany and Zoology 5(3): 1-7. doi: $10.5281 /$ zenedo.1024570.

[18] Monographie des essences forestières exportées du Congo, 1964.

[19] Boudru B, 1989. Forêt et sylviculture. Traitement de forêts. Presses agronomiques de Gembloux, 356 p.

[20] Guide de Vulgarisateur du code forestier en République Démocratique du Congo, 2002 et 2006: Foresterie communautaire.

[21] Ngbolua KN, Endowa DAJ, Masengo AC, Bongo NG, Toke NN, Djolu DR, Gbatea AK, Falanga MC, Ngelinkoto BMP, Mpiana PT (2018). Impact of Ichthyotoxic Plants on Biodiversity in the Freshwater of Businga Territory, Nord Ubangi Province in the Democratic Republic of the Congo. International Journal of Animal Biology 4(4): 45-51.

[22] DIAF (2017). Guide opérationnel-Liste des essences de la République Démocratique du Congo, Série : Généralités $-\mathrm{N}^{\circ} 2$, Version révisée. Ministère de l'Environnement et Développement Durable de RDC (MEDD) et Agence Française de Développement (AFD), 63p. 